\title{
Optimalisasi pendapatan asli desa (PAD) melalui pelatihan manajemen usaha bagi badan usaha milik desa (BUMDes) Desa Rejowinangun Kabupaten Blitar
} Afwan Hariri Agus P*, Subagyo, Lulu Nurul I, Deni Bagas P

Universitas Negeri Malang, Jl. Semarang No. 5 Malang, Jawa Timur, Indonesia *Penulis korespondensi, Surel: afwan.hariri.fe@um.ac.id

Paper received: 5-7-2021; revised: 23-7-2021; accepted: 30-7-2021

\begin{abstract}
Abstrak
Keberadaan BUMdes dalam rangka optimalisasi Pendapatan Asli Desa (PAD) dinilai menjadi sangat penting. Oleh karena itu pemberdayaan BUMDes menjadi salah satu langkah strategis dalam pembangunan desa. Kegiatan ini berfokus pada pendampingan manajemen usaha Badan Usaha Milik Desa (BUMDes) dalam rangka optimalisasi Pendapatan Asli Daerah dan mewujudkan kemandirian ekonomi desa di Desa Rejowinangun Kabupaten Blitar. Desa Rejowinangun memiliki potensi yang sangat bagus untuk dikembangkan baik itu pada sektor pertanian maupun UMKM. Kegiatan ini dilakukan dalam tiga tahap yaitu tahap persiapan, tahan pelatihan dan evaluasi kegiatan. Hasil kegiatan ini menunjukkan bahwa keberadaan BUMDes akan menjadi strategis bagi Desa Rejowinangun dalam rangka Pendapatan Asli Desa (PAD). Selain itu dari kegiatan ini diketahui bahwa pendampingan manajemen usaha bagi Badan Usaha Milik Desa Rejowinangun diperlukan sinergitas antara semua elemen desa dan partisipasi masyarakat desa untuk membantu kesuksesan program dari BUMDes dalam mendukung potensi yang dimiliki desa. Langkah ini dilakukan supaya potensi dari desa dapat dioptimalkan melalui keberadaan BUMdes, sehingga dapat terwujud kesejahteraan masyarakat desa yang merata dan kemandirian desa.
\end{abstract}

Kata kunci: manajemen usaha; BUMDes; pendapatan asli desa (PAD)

\section{Pendahuluan}

Berdasarkan Undang-Undang Nomor 6 Tahun 2014 Pasal 77 yang disempurnakan UU Desa tahun 2015 tentang Desa menyatakan pengelolaan kekayaan milik desa dilakukan untuk meningkatkan kesejahteraan dan taraf hidup masyarakat desa serta meningkatkan pendapatan desa. Permendagri Nomor 66 Tahun 2007 tentang Perencanaan Pembangunan Desa menjelaskan pemerintah desa bebas dalam mengelola, mengatur serta menentukan arah pembangunan desa secara mandiri. Hal ini didukung oleh Peraturan Menteri Keuangan Republik Indonesia No 4 Tahun 2015 menyatakan banyak yang bisa dilakukan oleh sebuah desa untuk meningkatkan pendapatan sendiri, salah satunya melalui BUMDes atau Badan Usaha Milik Desa.

Jumaiyah (2019), Venita (2016), Wirsa (2020) menyatakan bahwa BUMDes lahir dan mengembangkan dirinya sebagai lembaga usaha, berbasis potensi asli desa yang bakal memastikan seluruh warga desa bakal mendapatkan manfaatnya. Akan tetapi Senjani (2019) yang menyatakan bahwa peran BUMDes untuk meningkatkan Pendapatan Asli Desa belum dapat diperhitungkan secara jelas besaran kontribusinya.

Ketimpangan dalam pelaksanaannya dan hasil yang tidak merata serta manajemen usaha yang kurang tertata membuat perkembangan program BUMDes menjadi terhambat (IAI, 2021). Banyak BUMDes yang gagal, namun banyak pula BUMDes yang berhasil dan mandiri. Salah satu contohnya ialah keberhasilan BUMDes yang dicapai oleh Desa Sukamaju, Sumbawa 
Nusa Tenggara Barat pada Tahun 2012 yang memperoleh keuntungan Rp 263, 815 juta dengan jumlah dividen sebesar 79,115 juta untuk desa. Kontribusi dari BUMDes tersebut hamper sama besarnya dengan jumlah Alokasi Dana Desa (ADD) yang dialokasikan setiap tahun oleh pemerintah melalui APBD (Nugraha, 2014).

Untuk mencapai keberhasilan dalam pemberdayaan masyarakat, diperlukan adanya suatu pendekatan-pendekatan dalam pemberdayaan, Menurut Sumaryadi (2005) terdapat tiga pendekatan pemberdayaan masyarakat untuk mengoptimalkan BUMDes, yang pertama yaitu melalui melalui The Welfare Approach, pendekatan ini mengarah pada pendekatan manusia dan bukan untuk memberdayakan masyarakat dalam menghadapi proses politik dan kemiskinan masyarakat, tetapi justru memperkuat keberdayaan masyarakat yang dilatarbelakangi oleh kekuatan potensi lokal masyarakat, yang kedua The Development Approach yang bertujuan untuk mengembangkan proyek pembangunan untuk meningkatkan kemandirian dan kesejahteraan masyarakat, dan yang terakhir The Empowerment Approach yaitu pendekatan yang melihat bahwa kemiskinan sebagai akibat dari proses politik dan berusaha memberdayakan rakyat untuk mengatasi ketidakberdayaan masyarakat. Melalui ketiga pendekatan tersebut dengan didukung partisipasi yang tinggi dari masyarakat desa dalam mendukung program BUMDes maka potensi dari desa dapat lebih dioptimalkan sehingga BUMDes dapat berkontribusi besar Pendapatan Asli Daerah dan kesejahteraan serta kemandirian masyarakat desa.

Salah satu desa yang memiliki potensi yang menarik untuk dibina adalah desa Rejowinangun Kabupaten Blitar. Desa ini memiliki jumlah penduduk 3526 jiwa dalam 1153 Kartu Keluarga yang terdiri dari 1793 jiwa laki-laki dan 1733 jiwa perempuan.Selain potensi bidang pertanian, desa Rejowinangun juga terkenal dengan desa UKM. Desa Rejowinangun memiliki 80 UKM yang tersebar dalam 7 jenis produk yaitu: (1). Produk geti, (2). Produk jenang, (3). Produk kerupuk, (4). Produk tahu, (5). Produk dodol, (6). Produk Opak dan (7). Produk susu. Berikut ini merupakan contoh dokumentasi UKM yang beroperasi di desa Rejowinangun.

Tingginya potensi desa diatas ternyata tidak dimbangi dengan nilai pendapatan asli desa (PAD). Secara terpisah kepala desa Rejowinangun masih mengeluhkan keberadaan pelaku usaha di desa Rejowinangun hanya sebagai penyuplai produk bagi para tengkulak atau pedagang besar dari luar desa Rejowinangun. Begitu juga dengan pertanian desa, mayoritas petani menjual gabah hasil pertanian dengan harga dan keuntungan yang relative lebih rendah dibandingkan dengan menjual gabah yang yang sudah diproses menjadi beras. Padahal peran usaha mikro kecil menengah mampu menjadi sektor usaha terbesar kontribusinya terhadap pembangunan negara serta mampu membuka lapangan kerja (Wijanarko \& Susila, 2016)

Berdasarkan uraian di atas, diperlukan pelatihan dan pendampingan terhadap BUMDes sebagai upaya untuk pemberdayaan ekonomi masyarakat desa Rejowinangun. Ginandjar (1996) dan mardikato (2015) menyatakan bahwa pemberdayaan adalah upaya yang membangun daya masyarakat dengan mendorong, memotivasi dan membangkitkan kesadaran akan potensi yang dimiliki serta berupaya untuk mengembangkannya. Oleh karena itu, diperlukan upaya untuk untuk mempercepat laju BUMDes sebagai lokomotif peningkatan kesejahteraan warga desa Rejowinangun. 


\section{Metode}

Kegiatan Optimalisasi Pendapatan Asli Desa (PAD) Melalui Pelatihan Manajemen Usaha Bagi Badan Usaha Milik Desa (BUMDES) Desa Rejowinangun Kabupaten Blitar digambarkan skenario kegiatan sebagai berikut.

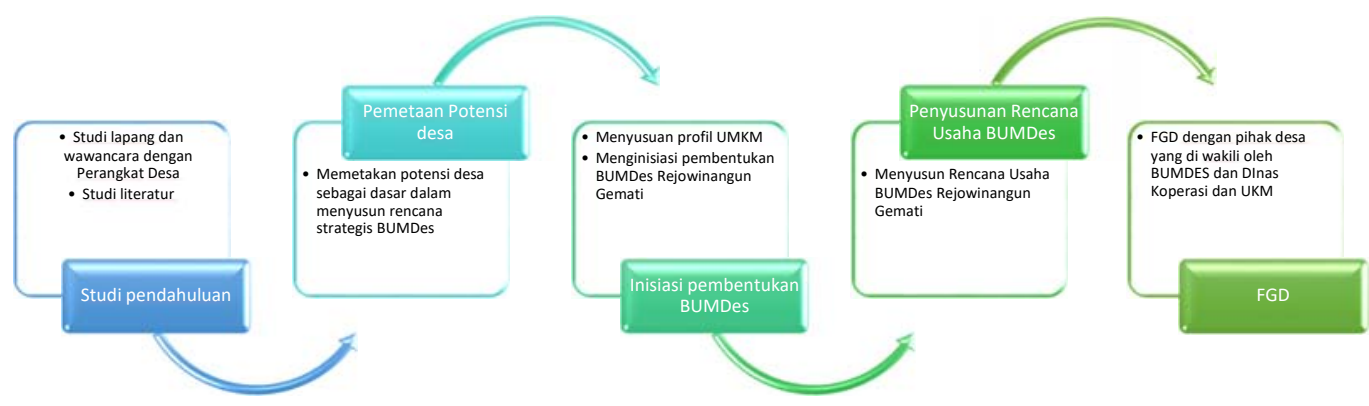

Gambar 1. Skenario kegiatan pendampingan

Tahap pendahuluan diawali dengan studi literatur kemudian dilanjutkan dengan studi lapang. Studi literatur dilakukan dengan mencari referensi mengenai konsep pemberdayaan BUMDes. Sedangkan studi lapang adalah melakukan observasi di lapangan dengan mengidentifikasi kondisi awal BUMDes. Oleh karena itu, hal pertama yang dilakukan oleh tim adalah mengidentifikasi kebutuhan akan informasi yang nantinya dijadikan sebagai dasar dalam menyusun rencana kegiatan pelatihan dan pendampingan bagi BUMDes.

Pada tahap selanjutnya adalah kegiatan pengambilan data lapang dalam rangka penyusunan peta potensi desa Bersama pengurus BUMDES. Peta potensi desa akan dijadikan dasar dalam menyusun Rencana strategi pengembangan usaha BUMDes Rejowinangun berdasarkan peta potensi desa. Pada tahap akhir kegiatan pelatihan ini adalah pelaksanaan FDG dengan para objek kegiatan untuk mendapatkan umpan balik kegiatan dan rekomendasi kebutuhan kegiatan pada tahun berikutnya.

\section{Hasil dan Pembahasan}

\subsection{Penguatan Manajemen Usaha BUMDes}

Tahap pertama dalam kegiatan ini adalah pembentukan BUMDes sebagai badan yang akan mengelola dan mengembangan potensi ekonomi yang dimiliki oleh desa Rejowinagun. Kegiatan pembentukan BUMDes di hadiri oleh: (1). Kepala desa. (2) Badan Permusyawaratan Desa (BPD). (3) Lembaga Pemberdayaan Masyarakat Desa (LPMD). (4) Pengurus PKK. (5) Pengurus Karang Taruna. (6) Pengurus Paguyuban UKM. (7) Pengurus Paguyuban petani Rejowinangun

Hasil FGD adalah landasan dalam pembentukan BUMDes yang dijelaskan sebagai berikut. 


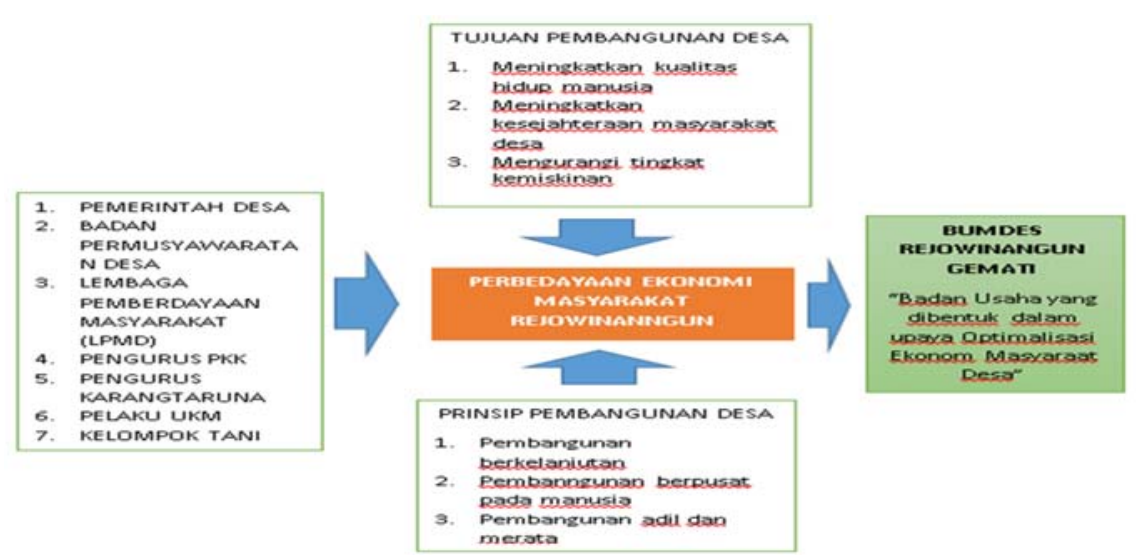

Gambar 2. Landasan pembentukan BUMDes

Berdasarkan gambar di atas, maka terdapat 7 pihak yang terlibat dalam pembentukan BUMDes Rejowinangun Gemati antara lain Pemerintah Desa, Badan Permusyawaratan Desa, Lembaga Pemberdayaan Masyarakat (LPMD), Pengurus PKK, Pengurus Karang Taruna, Pelaku UMKM, Kelompok Tani. Sedangkan dalam pembentukan BUMDes mengacu kepada prinsip dan tujuan pembangunan desa. Model di atas, terlebih dahulu ditetapkan sebagai acuan bagi perjalanan BUMDes kedepan.

BUMDes Rejowinangun disini akan berperan menjadi lokomotif pembangunan desa dengan dilatar belakangi oleh prakarsa yang sama antara pemerintah desa dengan masyarakat desa untuk mengelola BUMDes berdasarkan kebutuhan, potensi, dan kapasitas desa, serta penyertaan modal dari pemerintah Desa Rejowinangun baik dalam bentuk pembiayaan dan kekayaan desa yang bertujuan untuk meningkatkan taraf hidup masyarakat. Dalam pelaksanaanya BUMDes akan dikelola berdasarkan prinsip kooperatif, partisipatif, dan emansipatif dari masyarakat desa.

Oleh karenanya diharapkan BUMDes dapat menjadi penggerak perekonomian desa dengan menjalankan dua fungsi sekaligus yakni sebagai lembaga sosial dan komersial. Sebagai lembaga social BUMDes Rejowinangun akan selalu berpihak pada kepentingan masyarakat dengan berkontribusi menyediakan pelayanan sosial bagi masyarakat desa. Adapun dalam menjalankan fungsi komersial BUMDes Rejowinangun bertujuan untuk mencari keuntungan yang nantinya juga bisa meningkatkan pendapatan desa.

Dalam pelaksanaan BUMDes ini diperlukan sumber daya berupa: yang pertama, sumber daya manusia, dimana BUMDes Rejowinangun akan dikelola oleh pemerintah desa, badan permusyawaratan desa, lembaga pemberdayaan masyarakat, pengurus PKK, pengurus Karang Taruna, pelaku UMKM, serta kelompok tani. Yang kedua, sumber daya alam dan potensi desa lainnya, dalam hal ini Desa Rejowinangun memiliki sumber daya alam dan potensi desa yang sangat strategis untuk dikembangkan berupa wilayahnya yang memiliki banyak lahan pertanian serta potensi UMKM yang bisa dikembangkan. Yang ketiga, sumber daya finansial, yang mana ini merupakan modalitas untuk pelaksanaan program BUMDes yang akan disokong APB Desa selain itu BUMDes juga bisa berupa penyertaan modal masyarakat desa dan juga hibah pihak swasta. 


\subsection{Optimalisasi Pendapatan Asli Desa (PAD) melalui pemberdayaan BUMDes}

Berdasarkan Undang-Undang No. 6 Tahun 2014 Tentang Desa, Pendapatan Asli Desa (PAD) merupakan pendapatan yang berasal dari kewenangan Desa berdasarkan hak asal usul dan kewenangan skala lokal Desa. Pendapatan Asli Desa ini terdiri dari hasil usaha, hasil asset, swadaya dan partisipasi, gotong royong dan lain-lain pendapatan asli Desa. PAD juga merupakan salah satu sumber pendapatan desa yang digunakan untuk memperkuat keuangan, pembangunan serta pengelolaan desa. Oleh karenanya optimalisasi Pendapatan Asli Desa (PAD) sangatlah penting karena berdampak langsung pada pembangunan perekonomian desa.

Optimalisasi Pendapatan Asli Desa (PAD) salah satunya dapat dilakukan melalui pemberdayaan BUMDes. Hal ini karena BUMDes merupakan salah satu sarana perekonomian melalui berbagai jenis usaha yang sesuai dengan potensi yang dimiliki oleh masing-masing desa (Adawiyah, 2018). BUMDes sebagai penggerak perekonomian desa juga memiliki tujuan dalam menggali potensi desa yang ada untuk dijadikan Pendapatan Asli Desa (PAD) sehingga nantinya dapat mendukung biaya pembangunan desa melalui Anggaran Pendapatan dan Belanja Desa (APBDes) yang telah direncanakan oleh pemerintah desa setiap tahun (Irwan \& Bahriannor, 2019).

Dimana saat ini sudah ada banyak kajian empiris yang menerangkan peran BUMDes dalam optimalisasi PAD. Salah satunya yang dilakukan oleh Supardi \& Budiwitjaksono (2021) pada BUMDes Rosa Bungur Mandiri di Desa Bungurasih, Kabupaten Sidoarjo. Hasil penelitian ini menunjukkan pengelolaan BUMDes yang efektif pada BUMDes Rosa Bungur Mandiri dengan strategi mencari kerjasama dan investor, partisipasi masyarakat, serta pengelolaan aset desa. BUMDes memiliki pertanggungjawaban atas dana yang sudah diberikan oleh pemerintah desa, dan unit usaha pengelola aset juga mampu membuat perencanaan yang baik sehingga dapat memberikan dampak positif terhadap Pendapatan Asli Desa (PAD).

\section{Simpulan}

Berdasarkan hasil dan pembahasan di atas, maka dapat kesimpulan dalam kegiatan ini adalah sebagai berikut: (1) BUMDes merupakan salah satu wadah bagi pemerintah desa rejowinangun dalam rangka optimalisasi Pendapatan Asli Desa (PAD). (2) Optimalisasi peran BUMdes dalam rangka optimalisasi Pendapatan Asli Desa (PAD) dilakukan melalui kegiatan pelatihan penyusunan rencana usaha BUMDes

Melalui pembahasan dan berdasarkan temuan-temuan permasalahan UMKM di lapangan, maka berikut ini merupakan saran yang dapat dilakukan pada kegiatan selanjutnya: (1) Diperlukan peran dari pemerintah desa, tokoh masyarakat maupun kelompok pemuda dalam rangka penguatan peran BUMDes sebagai salah satu lokomotif dalam meningkatkan Pendapatan Asli Desa (PAD) desa Rejowinangun. (2) Dalam rangka optimalisasi kelembagaan BUMDes diperlukan pelatihan lanjutan terkait dengan peningkatan kompetensi SDM BUMDes dalam aspek pengelolaan keuangan dan pemasaran produk-produk desa.

\section{Daftar Rujukan}

Adawiyah, R. (2018). Strategi pengembangan badan usaha milik desa (bumdes) berbasis aspek modal sosial (studi pada bumdes surya sejahtera, Desa Kedungturi, Kecamatan Taman, Kabupaten Sidoarjo) (Doctoral dissertation, Universitas Airlangga).

Amirya, M. (2021). Peran Badan Usaha Milik Desa (BUMDes) Dalam Mendukug Kemandirian Ekonomi Desa. (Online). https://www.iaijawatimur.or.id/course/interest/detail/21. 
Desa, P. M., Tertinggal, P. D., \& Nomor, T. (4). tahun 2015 tentang Pendirian. Pengurusan dan Pengelolaan, dan Pembubaran Badan Usaha Milik Desa.

Jumaiyah, J., Wahidullah, W., Hidayat, S. H. S., Mudiarti, L., \& Aliyah, S. (2019). Manajemen Pengelolaan Bumdes Mandiri Sejahtera. SELAPARANG Jurnal Pengabdian Masyarakat Berkemajuan, 3(1), 117-119.

Indonesia, K. D. N. R., \& Nomor, P. M. D. N. (66). Tahun 2007 Tentang Perencanaan Pembangunan Desa.

Indonesia, P. N. R., \& Negara, B. (2015). Peraturan Pemerintah Nomor 47 Tahun 2015.

INDONESIA, P. R. Undang-Undang Republik Indonesia Nomor 6 Tahun 2014 Tentang Desa.

Indonesia, R. (2014). Peraturan Pemerintah No. 43 Tahun 2014 tentang Peraturan Pelaksanaan Undang-Undang Nomor 6 Tahun 2014 Tentang Desa. Lembaran Negara RI Tahun.

Irwani, \& Bahriannor. (2019). Pengelolaan Bumdes Hanjak Maju Dalam Berkontribusi Pada Pendapatan Asli Desa di Desa Hanjak Maju Kecamatan Kahayan Hilir Kabupaten Pulang Pisau. Jurnal Anterior, 19(1), $141-147$

Kartasasmita Ginandjar (1996). Pembangunan Untuk Rakyat: Memadukan Pertumbuhan dan Pemerataan, Jakarta: PT. Pustaka Cidesindo

Mardikanto Totok dan Soebiato Poerwoko. (2015). Pemberdayaan Masyarakat dalam Perspektif Kebijakan Publik, Cet. Ke-3. Bandung: Alfabeta

Peraturan menteri keuangan republik Indonesia No 4 Tahun 2015 tentang Badan Usaha Milik Desa

Senjani Y. (2019). Peran Sistem Manajemen Pada Bumdes Dalam Peningkatan Pendapatan Asli Desa. Kumawula: Jurnal Pengabdian Kepada Masyarakat. Vol. 2, No.1, April 2019, Hal 23 - 40

Sumaryadi, I Nyoman. (2005). Perencanaan Pembangunan Daerah Otonom dan Pemberdayaan Masyarakat. Jakarta. Penerbit Citra Utama

Supardi, E. L., \& Budiwitjaksono, G. S. (2021). Startegi Pengelolaan Badan Usaha Miliki Desa (BUMDES) dalam Upaya Meningkatkan Pendapatan Asli Desa di Desa Bungurasih. Jurnal of Economic, Management, and Accounting. Vol. 4 No. 2, Hal 139 - 148

Venita, dkk. (2016). Pemberdayaan Ekonomi Desa Melalui Badan Usaha Milik Desa (Bumdes) Desa Karangjaya Kecamatan Gegerbitung Kabupaten Sukabumi. Prosiding Seminar Nasional dan Call for Papers"Pengembangan Sumber Daya Perdesaan dan Kearifan Lokal Berkelanjutan VI" 24-25

Wijanarko A \& Susila I (2016) Faktor Kunci Keberhasilan UMKM Kreatif. Perubahan Kultur dan Sinergitas Bisnis. Sidoarjo: FEB Universitas Muhammadiyah Sidoarjo

Wirsa N. (2020). Keberadaan Bumdes Sebagai Pilar Pertumbuhan Ekonomi Desa Di Desa Telagatawang, Kecamatan Sidemen Karangasem. Parta: Jurnal Pengabdian Kepada Masyarakat. Vol 1 No 1 